\title{
MEDICAL PLANNING FACTORS *
}

\author{
Colonel A. J. SHAW, M.A., M.B., M.F.C.M., L/R.A.M.C. \\ Assistant Director-General Army Medical Services
}

Professions by their very nature depend upon a mixture of learning, skill and experience. They are not exact sciences and references to the "Physician's art" and the "art of war" underline this point. There is a tendency in times of peace and in the age of the academic in defence studies to deal in scenarios and to tailor-make contingency plans, but it is an old adage which reminds us that when the enemy has three courses of action open to him he will invariably choose the fourth. Nobody was more aware of the uncertainty of war than the Duke of Wellington who once said ${ }^{1}$ of the French Marshals that they planned their campaigns like a splendid set of leather harness which answered very well until it got broken; then it was useless. Now I, he added, make my campaigns with ropes. If anything went wrong, I tied a knot and went on!

Although we cannot reduce war to an exact science, we can and should make use of what facts and figures are available to assist our planning and make it as precise as possible. We must, however, be constantly aware of the circumstances from which the facts and figures have been derived in order to avoid making false assumptions and drawing ill-founded conclusions.

This paper will therefore review some of the planning factors which are in present use and consider their relevance for the future. They have necessarily been derived from past experiences over many campaigns. We must therefore ask ourselves whether they are still valid. How and to what extent can they be used to plan ahead? What new trends are developing which may affect their relevance? Should we attempt and are we able to be more precise in our predictions?

Medical planning factors may be defined as the data essential for effective planning of the provision and deployment of military medical resources. The basic factor on which all subsequent calculations rely is the anticipated total patient load and this is the most difficult to determine accurately. It has two components;

a. The battle casualty estimate. $b$. The non-battle casualty/sick rate.

Each component is a complete and complicated subject in itself and in this short paper I intend to confine my remarks to battle casualties. This is no way diminishes the importance of accurate estimation of likely non-battle casualties which in past campaigns have often greatly outnumbered the wounded and have presented a major challenge to the resources of the medical services. Their estimation demands a very thorough medical appreciation of the threat in the theatre of operations as a result of which an effective preventative medicine programme can be planned to reduce the incidence of disease to a minimum.

\section{The battle casualty estimate}

This is traditionally the responsibility for the general staff who are in the best position to assess the probable consequences of their operational plans. That they are not always completely accurate is illustrated by a reminiscence ${ }^{2}$ of a medical staff officer

* Paper read at the C.E.N.T.O. Military Medical Conference, Tehran 29th September to 3rd October 1975. 
in the first World War who wrote " in one battle the general staff of one of the armies gave us an estimate of 20,000 casualties, we prepared for 40,000 and we actually received 60,000 - the equivalent of three divisions!"

The keynote here is perhaps the word "battle" because in that war battles were still identifiable against a background of low key activity. Prior to 1914 much regard was given to the estimates of the Austrian General Cron who wrote ${ }^{3}$ : "Of a total force three-fifths would be engaged in actual fighting and will suffer 10 per cent casualties, therefore the total force would receive 6 per cent ".

This estimate was approximately true of the great battles of the Crimea ${ }^{4}$ : Alma 5.7 per cent. Inkerman 6.5 per cent. Redan I 5.9 per cent and Redan II 5 per cent and, when you remember that divisional fighting strengths were the basis for calculation, was in the right order of magnitude for the first World War ${ }^{5}$ where the average for certain specific battles was 9.5 per cent. The first day of the Somme in 1916 saw a 7.5 per cent British casualty rate. As a comparison the British casualty rates over the retreat from Mons in 1914 were 14.4 per cent in 7 days, and 36 per cent for the 5th Army and 21.7 per cent for the 3rd Army over the 14 days of the German offensive in 1918. But here the figures begin to blur from the set piece battle and reflect a sustained period of high activity but with inevitable areas of intensity and relative calm.

To move on to the second World War, General Cron's estimate equates well with the average casualty/day for a division in severe combat. These are the World War II casualty figures $^{8}$ (Table I).

Table I

Battle casualties (includes killed)

Expressed as a percentage of formation strength

\begin{tabular}{l|c|c}
\hline Formation & $\begin{array}{c}\text { Daily average for all days in action } \\
\text { (percentage) }\end{array}$ & $\begin{array}{c}\text { Severe battle day } \\
\text { (percentage) }\end{array}$ \\
\hline Brigade & 1.5 & 12 to 15 \\
\hline Division & 1.0 & 5 to 6 \\
\hline Corps & 0.5 & 2 to 3 \\
\hline
\end{tabular}

We can refine this still further by studying the likely results of specific types of operation. These are United States figures ${ }^{7}$ for divisional wounded per 1000 men per day. They should be corrected by a factor of 20 per cent for killed to give the total casualty rate (Table II).

Table II

Battle casualties for divisional wounded per 1000 men per day

\begin{tabular}{l|c|l|c}
\hline \multicolumn{1}{c|}{ Type of action } & Average & \multicolumn{1}{|c}{ Type of action } & Average \\
\hline Beach-head operations & 11.04 & Assault on fortified lines & 5.10 \\
\hline Offensive break-through & 7.14 & River crossings & 5.02 \\
\hline Reduction of ports and towns & 5.88 & Defensive (enemy counterattack) & 3.73 \\
\hline
\end{tabular}


From these figures we can derive an order of " casualty cost " for various types of operations ranging from the costly beach-head assault to the defensive. However this information is primarily useful to the tactical planners, the medical staff at the headquarters of formations about to undertake a specific type of operation. From it they can calculate evacuation requirements and decide on the deployment of medical units.

More necessary for the planner in times of peace are strategic data-total force casualty rates from which the required medical order of battle can be determined and the hospital bed cover requirement calculated.

From the latter viewpoint the overall experience in both British and American armies in World War II indicated that the average admission rate of wounded to hospital does not exceed 0.6 per cent per 1000 daily of the total force. Taking an average stay in hospital of 50 days this leads to a hospital bed requirement of 3 per cent of the total force. Add to this a dispersion factor of $1 / 5$ and a 2 per cent figure for non-battle casualties and sick in a temperate zone, the minimum bed requirement is therefore computed at 6 per cent ${ }^{8}$ :

$\begin{array}{ll}\text { Battle casualties } \quad 0.6 \times 50 & =3 \text { per cent } \\ \text { Non-battle casualties } 1 \times 20 & =\frac{2 \text { per cent }}{5 \text { per cent }} \\ \text { Add } 20 \text { per cent of above for dispersion factor } & =1 \text { per cent } \\ \text { Total percentage } & =6 \text { per cent }\end{array}$

In practice in World War II we deployed a bed cover of 4 per cent of the strength of the Force in North West Europe although the number required never exceeded 3 per cent and in addition set aside a further 3 per cent in the United Kingdom. Even with the heavy casualty rates in World War I a bed cover of 4 per cent in France with 8 per cent set aside in the United Kingdom proved sufficient ${ }^{9}$.

Since World War II the S.H.A.P.E. requirement for N.A.T.O. forces has been set at 16 per cent allowing for 50 per cent crisis expansion. The rationale for this high figure has never been substantiated but it was certainly laid down in the days when it was expected that the commencement of hostilities would coincide with the use of nuclear weapons.

The United Kingdom is at present conducting a very detailed study on operational medical support requirements and progress was held up for a considerable period for want of acceptable casualty estimates. Reference to historical data, exercise experience and the result of war games failed to produce a concensus and finally it was agreed to plan on the assumption that a formation engaged in combat ceases to be effective when it has suffered about 50 per cent casualties to its fighting units, the reason being that the force loses cohesion, partly due to co-lateral casualties and damage to its communications causing a breakdown of command and control, and partly due to effects on morale. Assuming formations would be fought to a standstill over a given number of days in combat, a daily casualty rate was derived estimating that support units would incur half 
the casualties of combat units. An accelerated rate was forecast after the advent of tactical nuclear weapons.

This estimate, however, relies on a specific scenario over a fixed number of days to determine the daily rate, but it does give an order of magnitude for planning purposes, although it greatly exceeds past experience and also the S.H.A.P.E. estimate.

Perhaps therefore it is worthwhile to leave statistics and percentages for a while (A cynical statesman once said that you might prove anything by figures ${ }^{10}$ ) and pose the questions what has changed since World War II and what effects are the changes likely to have.?

\section{Nuclear warfare}

The first and obvious change is the threat of nuclear warfare, the battle-field use of which no one happily has any experience. Clearly the prospect of widespread destruction would be enormously increased by nuclear weapons; but what will be their effect on the casualty rate? Certainly there will be vast numbers of casualties among civilians and refugees, but the same may not apply to the military. Tactics have responded to the threat and field formations deploy dispersed and hidden to make it difficult for the enemy to identify a worthwhile nuclear target. Very large numbers are unlikely to be affected, therefore, by any given tactical nuclear weapon and those who are casualties would number a high proportion of dead. Much more of a military threat is posed to the vulnerable, static and concentrated installations in the lines of communication.

\section{Chemical warfare}

Writing of experience in the First World War an American commentator ${ }^{11}$ said "With the exception of gunshot missiles (a very generic and comprehensive class) gas caused a far greater percentage of casualties than any other military agent used in the war, even including high explosive shells and shrapnel which were employed on a vastly increased scale."

Possibly due to international convention, but more probably from fear of retaliation, chemical agents have been used on very few occasions since 1918, but overtaken in horror by nuclear warfare, they constitute in a much more sophisticated form a considerable threat in future general war. Individual and collective defence measures are improving all the time but they pose an enormous tactical logistic problem. The lethality of the nerve agents, however, make it probable that a very large proportion of casualties would be beyond medical aid and there is more a problem of how the medical services would be able to continue to function effectively in such an environment.

\section{Conventional weapons}

Turning to conventional weapons probably the most significant advance is in the field of anti-armour weapons. The accuracy and effectiveness of infantry and helicopter borne anti-tank weapons have increased the vulnerability of tanks and armoured personnel carriers and this was borne out by the heavy armour casualties inflicted in the last Arab/Israel conflict-the Yom Kippur War of 1973. It is of interest that the casualty figures $^{12}$ from the war shewed a proportion of nearly 10 per cent burns casualties 
almost entirely incurred by crews of armoured fighting vehicles. This percentage is more than double the burns casualties experienced in previous conflicts and indicates a need to increase the provision of equipment and medical installations to deal with this type of case.

\section{Psychiatric battle casualties}

It is also noteworthy that Israel's figures ${ }^{12}$ for the Yom Kippur War shewed 10 per cent psychiatric battle casualties. This is a high proportion for a campaign of relatively short duration and has been ascribed to the surprise nature of the initial attack. It has been past experience that in adverse circumstances psychiatric battle casualties may comprise from 5 per cent to as much as 30 per cent ${ }^{13}$ of total casualties and are directly related to the degree of battle training and to the length of time troops have been exposed, under exhausting conditions to battle. It was, for example, recorded during the Second World War that first class, battle experienced divisions with a very low incidence of psychiatric breakdown would suddenly show a marked increase in psychiatric battle casualties if exposed to combat for too long a period.

Future conflicts may hopefully be restricted by political intervention to a limited duration which may reduce the percentage of psychiatric breakdown due to battle exhaustion but against this must be weighed limitations in battle training. Panic reactions and hysteria also may result from contact with chemical and nuclear weapons, and the uncertainties of the effect of such a war on a generation made aware of the casus belli by the daily bulletins dispensed by the mass media. Undoubtedly therefore psychiatric battle casualties will be a significant and possibly increased problem for the medical services.

Whether or not these trends justify our anticipation of a casualty rate greatly in excess of historical experience is a matter of discussion. In the past new weapons and threats have been counterbalanced by modifications in strategy and tactics, how else could the overall percentages have remained closely comparable from the Crimea to Korea? Nevertheless weapons of mass destruction may have changed all that; I offer no solution but suggest caution in projecting past experience to any future conflict the course of which is so unpredictable.

\section{Categorization}

Having accepted a total casualty estimate for planning purposes the next task of the medical planner must be to subdivide the total into treatment categories in order to determine the resources that will be needed to manage the anticipated load.

Mortality and survival statistics can be very confusing and depend to some extent upon the interpretation of the term " killed in action". We take this term to imply casualties who have died of wounds prior to evacuation from the regimental aid post; thus making no demands on medical evacuation and treatment resources.

Although one would expect that the increasing lethality of weapons will reduce the chances of survival this is offset by improvements in evacuation and treatment techniques and is illustrated by United States figures which shew a diminution of "deaths as a percentage of hits " as follows:

World War II 29.3 per cent. Korea 26.3 per cent. Vietnam 19.0 per cent ${ }^{14}$. 
Hospital mortality rates among the wounded also illustrate this point:

World War I 7.6 per cent. World War II 4.5 per cent. Korea 2.5 per cent. Vietnam 2.6 per cent. British Forces in Northern Ireland 4.6 per cent ${ }^{14}$.

The upward trend in Vietnam and Northern Ireland indicates the rapid evacuation of casualties who in other circumstances would have died before reaching hospital.

It is significant that during the Yom Kippur War with, of necessity, a more conventional evacuation system 22 per cent were killed in action and those casualties who died of wounds amounted to 1.9 per cent.

It may be fair to say therefore that for planning purposes approximately 20 per cent of total casualties will be killed in action, while those who subsequently die of their wounds will vary between 2 to 4.5 per cent depending on the effectiveness of evacuation and medical treatment.

The surviving 80 per cent of casualties may be divided into those who after treatment at a forward medical Installation in the divisional area are returned to their units and those that require surgical treatment under one of the three conventional surgical priorities:

Priority I-Urgent surgery and/or resuscitation. Priority $\Pi$ - -Early surgery and/or resuscitation. Priority III--Remainder of surgical cases.

Taking a wide range of previous experience to provide relatively crude planning figures we in the United Kingdom have subdivided these cases as follows:

Of 80 per cent surviving wounded-Priority I 15 per cent. Priority II 15 per cent. Priority III 40 per cent. Treated and Returned to Unit 10 per cent.

It is possible then for a given number of casualties to determine the evacuation facilities, surgical teams and hospital beds required for a formation of a known size.

\section{Conclusion}

In this very brief survey I have discussed the difficulties in arriving at credible casualty estimates for the future and have mentioned the trends which may affect the estimates. The danger of planning against specific scenarios has been pointed out.

How the medical services can apply to the total estimate factors which categorize casualties into evacuation and treatment priorities has been discussed and a percentage breakdown suggested.

The ever constant danger of high non-battle casualty rates from disease have been stressed and must never be underestimated.

Finally, I would suggest that we must apply the lessons of the past in planning the future but be mindful of the circumstances in which those lessons were learnt and watch for trends which may make them no longer applicable.

\section{BIBLIOGRAPHY}

1 The Great Duke (1971). Arthur Bryant. P. 206.

2 The Army Medical Services in War (1937). T. B. Nicholls. Bailliere, Tindall \& Cox. London. P. 4.

3 Ibid. P. 46.

4 Medical and Surgical History of the British Army which served in Turkey and the Crimea during the War against Russia 1854-56 (1858). Vol. II. Harrison \& Sons. London. Pp. 387-388. 
5 The Army Medical Services in War (1937). T. B. Nicholls. Bailliere, Tindall \& Cox.

6 Medical History of the Second World War-Medical Services in War (1968). Sir A. S. MacNulty and W. F. Mellow. H.M.S.O. London.

7 Battle Casualties (1952). G. W. Beebe and N. E. De Bakey. Charles C. Thomas, Illinois. P. 72.

8 . Medical History of the Second World War-Medical Services in War (1968). Sir A. S. MacNulty and W. F. Mellow. H.M.S.O. London. P. 139.

$9 \quad$ Ibid. P. 138.

10 Critical and Miscellaneous Essays-Chartisom--Thomas Carlyle.

11 Chemicals in War-Prentiss.

12 Department of Surgeon General, Israel Defence Forces.

13 Army Medical Service Bulletin No. 7 (1958). The War Office (A.M.D.7). London.

\section{Exhibition of the Works of John Hull Grundy at the Royal Army Medical College}

John Hull Grundy was Lecturer in Entomology at the Royal Army Medical College from 1942 until 1967, when he retired to the Hampshire countryside where he now lives. $\mathrm{He}$ is internationally known for his drawings of insects and other arthropods, but the considerable extent of his expertise, the wide scope of subject matter and the demands upon his artistic ability are not widely appreciated. About 150 framed examples of his diverse works, which include anatomical drawings, scenes from hospital life, drawings of animals and plants, book illustrations, and publicity material make up an exhibition in the Study Centre of the Royal Army Medical College, Millbank, London SW1P 4RJ, which will open on 6th December 1976 and run until 28th January 1977. 